Portland State University

PDXScholar

\title{
The Roots and Repercussions of Moroccan Soft Wheat Consumption, Production, and Import Patterns
}

Anna Murphy

Portland State University

Follow this and additional works at: https://pdxscholar.library.pdx.edu/honorstheses Let us know how access to this document benefits you.

\section{Recommended Citation}

Murphy, Anna, "The Roots and Repercussions of Moroccan Soft Wheat Consumption, Production, and Import Patterns" (2017). University Honors Theses. Paper 364.

https://doi.org/10.15760/honors.357

This Thesis is brought to you for free and open access. It has been accepted for inclusion in University Honors Theses by an authorized administrator of PDXScholar. Please contact us if we can make this document more accessible: pdxscholar@pdx.edu. 
The Roots and Repercussions of Moroccan Soft Wheat Consumption, Production, and Import Patterns

"Manage with bread and butter until God send honey." - Moroccan proverb

\author{
by \\ Anna Murphy \\ An undergraduate honors thesis submitted in partial fulfillment of the \\ requirements for the degree of \\ Bachelor of Arts \\ in \\ University Honors \\ and \\ International Development Studies
}

Thesis Adviser

Leopoldo Rodriguez

Portland State University 


\begin{abstract}
Following the conclusion of World War II, Moroccans' khobz-bread-consumption experienced one fundamental and detrimental change: the homogenization of recipes from an assortment of diverse ingredients, such as barley, winter wheat, durum, and seeds, to almost solely soft wheat. The homogenizing trend towards soft wheat is an outcome of Western influence, trade policies, international markets, economic growth and integration. Specifically, the United States' development initiatives-namely Green Revolution technology transfers and food aid-rendered detrimental effects on Moroccan wheat patterns of consumption, production, and import, which were further perpetuated and extended by Moroccan governance post-independence. Analyzing the ramifications of soft wheat patterns on agricultural development is more necessary than ever given the launch of Maroc Vert, a World Bank sponsored project championing development through agriculture stimulus. Overall, the deleterious wheat patterns in Morocco erode domestic production of other grains and co-opt farmland, destabilize the balance of payments, endanger food security, and stymie economic development in rural areas.
\end{abstract}




\section{Acknowledgements}

I would like to offer my sincerest gratitude first and foremost to my thesis advisor, Dr. Rodriguez who dealt with my never-ending emails, bouts of anxiety, and enthusiasm for such an obscure topic. None of this would have been possible without his time and help. Secondly, I would like to thank all the wonderful Moroccans who welcomed me into their homes and families, introduced me to their beautiful culture, and offered me a seemingly endless supply of khobz. What they taught me and how they shaped me is something for which I will never be able to repay them. I would, finally, like to acknowledge my family who read several drafts of my thesis throughout this process and listened to my prolonged ramblings about the nuances of Morocco's khobz consumption. 


\section{Table of Contents}

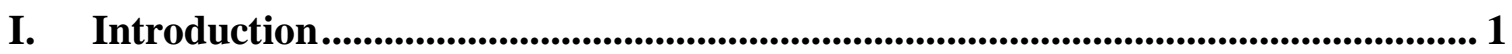

II. The Green Revolution and Food Aid:_......................................................... 5

A. The Green Revolution........................................................................................ 5

B. Food Aid.................................................................................................................. 7

III. History of Moroccan Agriculture ............................................................................ 11

IV. Maroc Vert and Morocco's Present Agrarian Landscape .................................. 16

V. Wheat Patterns and Policies ................................................................................ 19

A. Grain diversity ............................................................................................................... 24

B. Economic Performance ............................................................................................... 26

C. Food Security................................................................................................................... 28

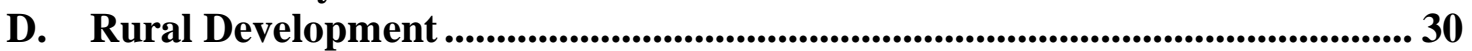

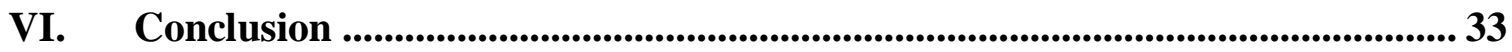

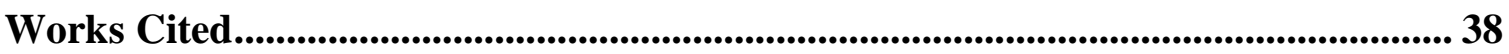




\section{List of Figures}

GRAPH 1: Wheat Patterns in Morocco 1960-1979 (1000 MT) ..................................... 21

GRAPH 2: Moroccan Wheat production and imports 1980-2016 (1000 MT)................ 23

GRAPH 3: Planted Barley and Wheat 1960-2016 (100 Hectares) ................................ 25

GRAPH 4: Soft Wheat and Food Price Index 1979-2016 (USD) .................................. 29 


\section{Introduction}

Khobz, the transliteration of bread in Arabic, is an essential staple of the Moroccan diet. From a breakfast of khobz, pastries, olive oil, honey, butter and jam, a lunch tagine with khobz, an evening snack of khobz and cheese, to a supper of khobz alongside harira (soup), khobz is the primary accompaniment and utensil of most Moroccan meals. In cities, khobz is found en masse across hanoots (neighborhood corner shops), bakeries, grocery stores, traditional souqs (outdoor markets), foorns (public ovens), and more. In rural areas, khobz is often prepared in the home and can be baked in the local foorn. Khobz is a fixture of most every meal and found on every street corner. Used as a fork and spoon, and a centerpiece of every celebration and gathering, it is thus not only a diet staple, but also a quintessence of Moroccan culture, spanning both rural and urban areas, past to present.

Yet, following the conclusion of World War II, Moroccans' khobz consumption experienced one fundamental and detrimental change: the homogenization of recipes from an assortment of diverse ingredients, such as barley, winter wheat, durum, and seeds, to almost solely soft wheat. Now, as Morocco industrializes, urbanizes, and develops, khobz consumption and production patterns adversely impact Morocco's balance of payments, food security, and development of rural and agricultural regions, which raises questions about the sustainability of this cultural diet practice in Morocco's future. In this thesis, I explore why soft wheat swelled in use and demand in Morocco to supplant other cereal grains. From there, I analyze the present repercussions of this phenomenon on Moroccan small farmers, agricultural policies, and, more generally, economic development. 
Understanding the shift from diverse cereal grains to a predominance of soft wheat in the Moroccan diet requires the analysis of economic policy, both domestic and international, and its impact on the convergence of grain production and consumption in Morocco. To facilitate this critique, I employ secondary sources-books, academic journals, and reports—-published in the last half century by international organizations (e.g. OECD, FAO, UN, and World Bank) supplemented by additional independent researchers. The analysis of diverse sources allows me to study links - as they pertain to the research questions at hand-that have been previously underexplored. Current literature exists, first, on agriculture (Ghanem 2015, Swearingen 1987, and World Bank 2013), the Green Revolution (Pingali 2012 and Stavrianos 1981), and food aid (Barrett 1998, Cleaver 1972, and Hodges 1983), and, second, on wheat production and consumption (Hodges 1983 and Arrisueño, Ahmed, Hamrick, Nahapetyan 2016) and the impacts of these on Moroccan society (Davis 2006 and Fardaoussi and Hanson 2016). Yet, the literature lacks a discussion on how agricultural development and food aid have influenced wheat production, consumption, and import in Morocco or the larger impacts of this phenomenon on Moroccan society. This thesis aims to forge a pathway for discussion and further research on this topic and weave a more complete narrative about agricultural policy, rural development, economic growth, and-most importantlykhobz.

Analyzing the ramifications of soft wheat patterns on agricultural development is more necessary than ever given the launch of Maroc Vert, a World Bank sponsored project championing development through agriculture stimulus. According to the Moroccan Government (n.d.), agriculture is the greatest driver of sustainable economic 
growth, citing agriculture as a driver of GDP growth, job creation, and export development, as well as an antidote for rural-urban inequality and food insecurity. In terms of economic composition, agriculture contributes to 13.8 percent of Morocco's GDP and employs 39.1 percent of the labor force (CIA n.d.). Moreover, agriculture is crucial for Morocco's economic outcomes.

Per the latest UN Human Development Report, Morocco scored .628 in the Human Development Index, HDI, ranking 126 out of 187 countries. Morocco ranked only above Yemen in the MENA region in terms of development (UNDP 2015). Notably, the HDI diminishes significantly in rural areas (CIA n.d.). Morocco's Gini Coefficient is .41, which places it 129th in the world in terms of equality (UNDP 2013). Urban-rural inequality is likely a significant factor. In total, almost 20 percent of Moroccans live in poverty or under its threat, and nearly two-thirds of these persons reside in rural areas (World Bank 2013, 4). Therefore, economic development as a means to reduce inequality and increase national economic outcomes is vital; and, employing agriculture as a mechanism for this necessitates exploring the role and ramifications of soft wheat production, consumption, and import patterns on agricultural output and productivity. Soft wheat occupies over 40 percent of utilized agricultural area in Morocco (Fardaoussi and Hanson 2016), represents 40 percent of daily caloric intake (Santos and Ceccacci 2015), and is the fifth largest import (OEC, n.d.). Soft wheat's distinctive rise in demand fueled the usurpation of agrarian land for its production alongside a substantial increase of its imports, which together pose a series of economic and agricultural challenges for Morocco's development initiative. 
The homogenizing trend towards soft wheat is an outcome of Western influence, trade policies, international markets, economic growth and integration. Specifically, the United States' development initiatives rendered detrimental effects on agriculture across the Global South, as it extended its own agricultural systems outward and scrapped traditional farming practices in favor of technology intensive, export-oriented agriculture. However, the extent of the effects of US aid and intervention is in part shaped by the policies developed within recipient countries as a response to US involvement. In sum, the United States' foreign and agricultural policies-namely Green Revolution technology transfers and food aid—alongside Morocco's governance, in the post-World War II era, subsidized the consumption of soft wheat in Morocco and created an unprecedented demand for khobz baked from this grain type. These factors eroded domestic production of other grains and co-opted farmland, destabilized the balance of payments, endangered food security, and stymied economic development in rural areas. 


\section{The Green Revolution and Food Aid:}

The United States magnified its cultural, political, and economic influence in the post-World War II era as the Cold War stoked competition for hegemony through strategic alliances, economic influence and prosperity, and global outreach. While the scope of this outward projection exceeds the bounds of this thesis, two pertinent mechanisms by which the United States exported its ascendancy and encouraged-or manipulated - the adoption of its systems, policies, and structures across the Global South are notable. The Green Revolution and Food Aid were manifestations of US economic and agricultural policy towards the Global South. The implementation of these policies reframed agriculture in the Global South, the effects of which remain today.

\section{A. The Green Revolution}

In the wake of a looming food crisis in the post-World War II era, caused by massive population growth, droughts, soil erosion, and increases in land value, the Global South embarked on a period of unprecedented agricultural growth. During the Green Revolution, spanning decades from the mid-1960's to the 1990s, the amount of land cultivated increased by only thirty percent, but annual crop yields tripled as a result of investment into infrastructure, crop research, and the invention and diffusion of technology (Pingali 2012).

The research and technologies that fed the Green Revolution took place in the United States in the early 1940's, when American agriculture experienced a shift from small plot farming to "a high technology, energy intensive food system in which agribusiness corporations dominated all links of the production chain" (Stavrianos 1981, 
440). At the conclusion of World War II, and in the onset of the Cold War, the United States began exporting this new agricultural system abroad (Cleaver 1972). Indeed, the United States played a pivotal role in the onset and longevity of this revolution by investing in agricultural technologies and their subsequent diffusion into developing nations. According to Clifford Harden, former Secretary of Agriculture, the Green Revolution was "the greatest success story of foreign aid since the Marshall plan" (United States Congress 1969).

The development of high yielding variety (HYV's) seeds, the expansion of irrigation systems, and the generous application of synthetic fertilizers and pesticides were the backbone of the Green Revolution. Improved seeds, and increased access to water and agrochemicals led to a growth in annual yields of 208 percent for wheat, 109 percent for rice, and 157 percent for maize between 1960 and 2000 (Pingali 2012). Notably, Pingali (2012) found that without the Green Revolution, calorie intake would have likely been 10 percent less, world food prices 35 percent higher, and food production 20 percent lower. Thus, the Green Revolution helped avoid famine, reverse malnutrition, and disseminate agricultural technology in the newly independent and rapidly growing Global South.

Yet, the Green Revolution simultaneously generated adverse results and sowed consequences that continue to plague the Global South. For instance, the Green Revolution warranted investments in selected agrarian areas where environmental, political, and economic situations were favorable. As a result, intra-country, as well as intra- and inter-regional inequality, tended to increase. Investments focused on particular crops and farming techniques, ignoring the diversity of farming across the globe and 
within countries (Wolf 1986). Thus, traditional, non-staple crops were swapped for more profitable staple foods such as wheat or rice; and, as the supply of non-staple crops declined, their prices increased straining poor consumers purchasing power, leading to their substitution with massively produced staple crops. While an upswing in calorie consumption during the Green Revolution combatted starvation, the calories consumed often declined in nutritional diversity. Furthermore, the intensification of production and homogenization of outputs fostered unintended environmental consequences including resource depletion and soil degradation (Pingali 2012).

The Green Revolution also empowered agri-businesses that were often foreign owned, occupied the most fertile land, and could afford new technology (Wolf 1986). The rise in large, foreign agribusinesses reduced competition, particularly from small subsistence farmers, ultimately feeding rural unemployment and rural-urban migration. To afford patented machinery, seeds, or fertilizer, landowners adopted labor saving techniques in order to remain profitable, which further expanded unemployment and the erosion of traditional agrarian lifestyles (Stavrianos 1981, 441-42). Furthermore, technology transfers during the Green Revolution largely surpassed women farmers, thereby intensifying gender inequality (Pingali 2012).

\section{B. Food Aid}

The United States Food for Peace-food aid-program, which commenced in 1954 under Public Law 480, authorized the export of surplus food commodities as a form of development assistance (Stavrianos 1981, 442-43). Importantly, food aid remains a pillar of US development policy today, although the structure and laws governing how 
and when it is given have changed (Barrett 2006). Food for Peace was a dichotomous form of assistance intending to alleviate hunger, reduce import costs, and encourage agricultural development for developing nations, while also aiming to find markets for US agricultural outputs that exceeded local demand and consumption in order to prevent flooded markets and price collapses domestically.

Indeed, food aid can allay hunger in crisis situations when drought, poor resource management, population growth and urbanization threaten malnutrition and starvation. The relief of import payments and the creation of counterpart funds also extricate monetary resources for investment into infrastructure projects, public service, agrarian technology and research. However, its effects were far more negative. Food for Peace rendered countries dependent on the program's low cost imports. The subsidized price of food rendered domestic farmers unable to compete, which retarded the overall development of domestic agriculture sectors and magnified countries' food needs in years when food aid failed to manifest (Barrett 1998). Further, Barrett (1998) found that food aid artificially depressed food prices and therefore encouraged the production of nonfoodstuffs and non-agricultural materials because they were more financially beneficial.

Moreover, it is not surprising that the "graduation rate"-meaning countries who no longer receive donations-is unimpressive. Barrett (1998) discovered that between 1955 and 1995, the 153 recipient countries shared a mean of 19 annual donations. And, the 21 years in which food aid was not received were often years when food prices were higher and donor countries were less inclined to make donations, despite these being times when recipient countries were most in need of PL 480 stores. This trend becomes further problematic if recipient countries invested into large-scale projects with the extra 
monetary funds they were expecting to save from food aid. Then, in years when food aid failed to manifest, they were required to participate in deficit spending to compensate (Barrett 1998).

Barrett (1998) found that of the countries receiving food aid prior to 1990, 64 percent collected it more than once; 74 percent of countries that began their tenure as food aid recipients between 1965 and 1989 were still beneficiaries by the turn of the millennia; and in the 1990's, 52 percent of countries that had been recipients in the 1950's no longer obtained it. Barrett (1998) remarks that these figures "overstate the 'graduation rate' because [they] include states dropped for purely political reasons (e.g. Cuba, Iran, Libya, and Syria)." Moreover, while food aid promised lower prices on food staples, it eroded domestic production, obliterated local competition, and decelerated the development of agricultural sectors in recipient countries, which all confute claims by lawmakers and other stakeholders in PL 480's longevity. Further, a growing discourse community asserts that food aid was a mechanism for trade promotion and a marketing device for donor countries' products that stimulated their popularity among the local population and developed means for distribution (Barrett 1998). In addition, the limited variety of foodstuffs delivered through food aid often hijacked local diet practices and increased demand for common food aid products (Hodges 1983, 16 \& 32). Under food aid, developing—often agrarian—countries metamorphosed to net food importers, which serves as a testament to the failure of PL 480 in fostering agricultural development.

When considering the ramifications of the Green Revolution and food aid, perpetuated by US foreign and agricultural policy, it is necessary to recognize that these forces occurred simultaneously. While not conceived as a uniform strategy, the Green 
Revolution and food aid necessarily informed the other and magnified its results. Together, they succeeded in reducing hunger and increasing overall food availability and circulation. However, they also resulted in the loss of livelihoods, erosion of farmland and natural resources, and the distortion of diet traditions. For certain groupsparticularly the poor and agriculturally dependent — the Green Revolution and food aid engendered food insecurity, corrosion of small farming, greater inequality, and impediments toward rural development.

As a developing and agriculturally dependent country, Morocco's economic development has been heavily influenced by food aid and Green Revolution policies. Given its proximity to Europe and its political and economic alliances with the United States, Morocco serves as a robust case for examining the effects of US aid and agricultural policy in the post-World War II era. Specifically, Morocco's soft wheat production, consumption, and import patterns have been directly influenced by these policies. For Morocco to maintain its agricultural strength in the region, relatively stable economic output, and development initiatives, the government will need to rectify soft wheat production, consumption, and import practices. 


\section{History of Moroccan Agriculture}

Familiarity with the history of Moroccan agriculture elucidates several points surrounding the effects of Green Revolution technology transfers and food aid in Morocco. Their potentially negative impact, coupled with Moroccan agricultural policy in the following decades, led to far reaching consequences on wheat production, consumption, and import patterns. Across this history, several themes arise: the expansion in the production of soft wheat was externally prescribed, agricultural policies assigned soft wheat farming to small farmers, and small farmers were remanded to nonirrigated, unfertile, and segmented land, which caused greater inequality. The Bildungsroman of modern Moroccan agriculture is marked by failed, miscalculated foreign and domestic policy initiatives, as well as manipulation by European, US, and agribusiness interests.

The establishment of the French Protectorate in Morocco in 1912 launched the mutation of Moroccan agriculture into its current condition. Until the early 1930's, the Protectorate's agricultural policy centered on wheat farming due in part to a food crisis in France in 1916, which eroded domestic wheat output (Swearingen 1987, 16-20). To stimulate wheat production, the French government offered loans for land and seeds to French settlers. France also artificially maintained the price of wheat at three times the world average. The price manipulation was compounded by a series of droughts and locust infestations that further increased prices by hindering yields. The results were several fold: Moroccan consumers were financially strained by unaffordable wheat prices and suffered malnutrition as inequality and poverty spiked; small-scale Moroccan producers were unable to compete with French settlers occupying large farms so 
inequality was further magnified; and the annexation of land by French settlers initiated the displacement of small farmers - and with them, crops for domestic consumption- to less-fertile land (Swearingen 1987, 18-25).

With an oversaturation of wheat internationally and a series of plagues in Morocco, the French, by the late 1920 's, halted wheat production as a mechanism of colonization. The new focus after 1930 was shifting large, French farms to producing irrigated vegetables and citrus fruits. In this time, Moroccan agriculture evolved to a technology intensive, agribusiness-dominated affair dictated by non-state actors, such as French businessmen, settlers, etc. (Swearingen 1987, 59-61). Citrus plants, which were almost exclusively concentrated on settler land, were the predominant means for installing the new model in Morocco. In fact, between 1935 and 1943, the amount of exported citrus doubled; and by 1956, it had grown by a factor of 10 (Swearingen 1987, 62-63). Settlers earned sizable profits through the export of their yields while simultaneously expropriating land previously dedicated to crops for domestic consumption. This led to the concentration of the ownership of the best agricultural land in the hands of French settlers dedicated to the production of export crops. To reconcile the settlers' shift to citrus for export with domestic food needs, the Protectorate imposed the production of staple crops - namely wheat and other grains-on Moroccan farmers. Profits from grains paled compared to citrus, and therefore inequality in the agrarian landscape grew (Swearingen 1987, 70-75).

Around the same time, the Protectorate initiated a program that redrew small farm holdings to fit into a more grid-like, rural landscape, altering small farmers' land possession. (Swearingen 1987, 95-100). The French also launched a wide-scale campaign 
of land reclamation to provide Moroccan peasants with arable land (Swearingen 1987, 95-100). The goals of these initiatives included improving irrigation management among small farmers. These projects, however, halted as Europe was drawn into war. (Swearingen 1987, 103-04).

At the end of World War II, the French reinvested time and money into Moroccan agriculture. The new focus was large-scale irrigation, which intended to maintain land reclamation efforts and increase productivity. These policies protected settlers' holdings and hegemony. To gain access to government funded irrigation and reclaimed land, Moroccan peasants were required to submit to stringent regulation, which included redrawing Moroccan farm holdings and regulating the production of certain-less profitable — crops, such as legumes, cotton, alfalfa, and wheat (Swearingen 1987, 145). A critical development was the homogenization of grains to wheat. The Protectorate attempted to eliminate all maize production and supplant barley crops with wheat (Swearingen 1987, 115-18). Under these plans, Moroccans were also pushed either to reclaimed land or fringe fertile land, which lacked proper access to irrigation or whose surface water was being re-routed to land reclamation efforts. In fact, by the dawn of the 1950 's, settlers, who were .5 percent of Moroccan landowners, owned half of Morocco's irrigated land (Swearingen 1987, 143-44). Overall, land reclamation and large-scale irrigation further engendered inequality, marginalized Moroccan farmers, and enforced wheat production among small farmers.

Morocco achieved independence in 1956, but French agricultural policies continued to haunt and inform management of farmland and the agrarian industry by Morocco's government. The Moroccan government assumed control over most facets of 
the agriculture, and launched a plan to achieve food self-sufficiency. At the time, the biggest agrarian dilemma was the juxtaposition of modern and traditional agriculture holdings. A series of failed agricultural development policies focusing on mechanization and irrigation initiatives, which were homages to the Green Revolution, stymied rural development and reinforced juxtaposition of farm ownership and persistent inequality while eroding the ability of Morocco to feed its population (Swearingen 1987, 143-59).

Post-independence also witnessed the involvement of international institutions. The most notable of these was the World Bank, which entered Morocco in 1964 and resurrected policies of land reclamation and heavy irrigation. The loans and investments from the World Bank ensconced the juxtaposition of Moroccan farming by favoring cultivated land with modern irrigation, which housed large farms producing citrus and vegetables intended for export. Further, irrigation development materialized through large-scale projects like dams and canals, which did little to improve irrigation for small farmers and eroded farmland located near construction zones (Swearingen 1987, 159171). In 1978, the World Bank prepared a report that further indicated the need to mechanize vegetable and fruit farming. The report also reinforced cereal production in the traditional sector (World Bank 1978). The World Bank's concentration on large-scale irrigation, mechanized agriculture, land reclamation, and a small selection of crops were all facets of the Green Revolution actualized in Morocco. Overall, investments that benefit large-scale farming producing export-oriented crops and possessing fertile land, undermined the position of small-scale farmers, once again reinforcing inequality and encouraging wheat production by small farms. 
Post 1980, Morocco embraced a more liberalized agrarian approach, which included deregulation and privatization. Notably, such reforms in the cereal sector were postponed (Arrisueño, Ahmed, Hamrick, and Nahapetyan 2016). From 1980 to 2000, Morocco participated in a series of structural adjustment initiatives (Wacziarg and Welch 2008), such as tariff reduction and export intensification. The Moroccan government also embraced privatization and investment into large, export oriented agricultural landholdings. The liberalization period in Moroccan agrarian policy extended the decades long fixation on export-oriented agriculture that largely ignores small farmers because of lack of access to capital and technology needed to compete with large farmers in this sector. Overall, this perpetuated the farming of less profitable outputs among small farmers for domestic consumption, which is mainly wheat (Davis 2006). Moreover, economic policies in post 1980's Morocco continued the inequality between large and small farmers.

Overall, the history of Moroccan agriculture is a narrative riddled with failed and mismanaged policies that benefitted the export sector while ignoring the domestic. The ramifications of the policy failures are the concentration of wheat production in the hands of small farmers and the expropriation of fertile land by large export oriented farmers, resulting in the persistent inequality that plagues Morocco's rural landscape. Seeking to invigorate the agricultural sector, Morocco is in the midst of a World Bank sponsored project called Maroc Vert, which extends from 2008 to 2020 and is supported by a 300 million EUR loan given in two installments. 


\section{Maroc Vert and Morocco's Present Agrarian Landscape}

Maroc Vert centers on four policy pillars: domestic markets, governance, agricultural services, and irrigation (World Bank 2013, 24-31). Maroc Vert intends to streamline domestic markets in both the fruit and vegetable sector as well as the meat industry by creating institutional regulations for domestic wholesale markets and improving frameworks governing slaughterhouses (World Bank 2013, 26-29). The governance pillar aims to integrate small farmers into larger value chains by institutionalizing contract farming. The focus on agriculture services aims to maximize the effects of Maroc Vert by allowing stakeholders to suggest, propose, and implement projects (World Bank 2013, 30-32). The pillar also focuses on building and maintaining a food safety control system, which primes crops for export (World Bank 2013, 33-36). Finally, the concentration on irrigation intends to improve aquifer use and increase the use of drip irrigation. Maroc Vert also seeks to privatize irrigation and improve it through better government planning (World Bank 2013, 37-41).

The second pillar aiming to institutionalize contract farming to improve access of small farmers to value chains is worth analyzing in the context of this thesis. Contract farming occurs when smaller shareholders engage in contracts with larger shareholders, who invest into their smaller partners. Contract farming secures a market for producers and establishes lines of credit and investment for the smaller shareholders, while also guaranteeing the larger shareholder has access to a desired quantity of goods produced at a specific quality (World Bank 2015). The former two items can help smaller farmers in Morocco gain access to needed fiscal resources for mechanization, irrigation, crop 
diversification, etc. Overall, this has the potential to address two of the biggest barriers impeding agricultural development: land segmentation and lack of biodiversity.

Land segmentation and lack of biodiversity are direct outcomes of previous agricultural policies. There are roughly one and a half million farm holdings in Morocco: 4.3 percent of these are landless (i.e. livestock grazing), 70 percent are less than five hectares, and four percent are more than 20 hectares (Berkat and Tazi 2006). Yet, about 75 percent of Morocco's agrarian land is under control of large corporate farms that earn roughly nine times more than their smaller counterparts, indicating inequity in both land distribution and profits (Ghanem 2015). Morocco's agricultural history witnessed the spike in inequality and the imposition of wheat production primarily among small framers' holdings. Lack of biodiversity is the result of cereal predominance, namely soft wheat. On average, the breakdown of annual products is as follows: 43 percent cereals, seven percent plantation crops (olives, almonds, dates, citrus fruits), three percent pulses, two percent industrial crops (sugarcane, cotton, etc.), two percent forages, two percent vegetables, and 42 percent fallow (Global Yield n.d.).

Contract farming can transcend segmentation which has been difficult to manage in past development initiatives and can contribute to crop diversification. However, contract farming presents several challenges: it can further engender inequality, avoid unfavorable land, impede farmer's autonomy, foster dependency, and reduce crops for domestic consumption (Bijman 2008). Thus, the potential for failure or minimal gain is also high.

Overall, the actualization of Maroc Vert seems to mimic past agricultural reform initiatives. Maroc Vert focuses on irrigation, mechanization, streamlining, and 
organization, which skirt small farmers. Hicks (2015) argues "[Maroc Vert] has focused too heavily on large-scale production, putting the interests of agribusiness aimed at export ahead of the needs of poor farmers in rural areas." Indeed, without improved support for small farmers, they are likely to continue to flounder.

In the rest of the thesis, I analyze the ways in which insufficient biodiversity and the reign of soft wheat negatively impacts small farmers and consequentially Morocco's agricultural and economic development and destabilizes other sectors. Now, as Morocco embarks on Maroc Vert to stimulate rural development through agriculture, understanding the importance of wheat, which uses large swaths of land and whose production is concentrated among small, non-irrigated, and segmented family farms, is critical. For Morocco to maintain its agricultural strength in the region, relatively stable economic output, and development initiatives, the government will need to rectify soft wheat production and consumption practices. Overall, Morocco's wheat patterns of production, consumption, and imports were heavily influenced post World War II by the Green Revolution and food aid as well as Morocco's domestic policies. Together, these yielded negative outcomes for grain diversity, economic performance, food security and rural development. 


\section{Wheat Patterns and Policies}

The production, consumption, and import patterns of wheat in Morocco have been heavily influenced by the United States' foreign and agricultural policies-namely Green Revolution technology transfers and food aid-alongside Morocco's agricultural governance in the post-World War II era. Both of these subsidized the consumption of soft wheat in Morocco and created an unprecedented demand for khobz baked from this grain type. The influence of US foreign policy in Morocco's rural landscape began around Morocco's independence. At this time, Morocco intended to remedy the suboptimal economic and political climate post-independence by initiating an effort to achieve food self-sufficiency by the 1960's (Hodges 1987, 112). To the Moroccan government, a favorable mechanism for this was soft wheat. Cultural traditions instilling khobz as a centerpiece of the diet, the prevalence of wheat farming, the availability of soft wheat HYV's vis a vis the Green Revolution, and the flood of soft wheat through PL 480, combined to influence this choice.

The government worked to increase domestic wheat yields through subsidies for inputs, such as fertilizers and HYV seeds. By 1973, 40 percent of all wheat acres were sowed to HYV's (Hodges 1983, 109). As a result, wheat production grew 5.1 percent annually between 1960 and 1979 (Hodges 1983, 113). At the height of food aid flows to Morocco in 1965, soft wheat inflows through the program amounted to 400 thousand metric tons (Hodges 1983, 140), flooding the domestic market with cheap soft wheat. Food aid, in combination with the Green Revolution, resulted in increased soft wheat available in the domestic market at artificially low prices. 
As it pertains to wheat consumption in Morocco, Hodges (1983) deduces that Morocco used PL 480 soft wheat imports to subsidize demand of khobz (109-10). Further, Morocco employed food aid as a substitute for other imported foodstuffs, flooding grain markets with soft wheat while simultaneously stripping them of other products (145). The Government also set the price of wheat (110), rendering it a cheap calorie substitute for other, more expensive foods. Together, these resulted in artificially depressed prices for khobz and rising consumption.

Another feature of the government's wheat policy was stockholding, which aimed to maintain an adequate soft wheat supply despite volatile amounts of soft wheat in PL 480 shipments and domestic production, as well as fluctuating wheat supplies and prices in the international market. In fact, fear of rising wheat prices caused the government to increase stockholding measures during years when wheat prices were above average (Hodges 1983, 145). The consequences of this were threefold: expanded wheat stores, increased amounts of subsidized wheat in the domestic market, and heightened government spending because wheat stock was often expanded in years of inflated prices. In 1981, when the World Bank was involved in market reforms in Morocco, the government attempted to rectify the disparity between the real cost and consumer price by increasing soft wheat prices, but backtracked quickly after riots erupted in Casablanca (Hodges 1983, 180).

Hermann, Prinz, and Schenck (1992) indicate that when food aid is used to subsidize demand, demand for the product increases. This implies that Morocco's uses of food aid likely increased demand for soft wheat. Likewise, Hodges (1983) concludes that depressed wheat prices promoted its consumption in Morocco (115), adding that the 
greatest increase in soft wheat consumption occurred in urban areas where government controlled imports were easily distributed (139). Graph 1 illustrates the changes in wheat production, consumption and import patterns in Morocco during and immediately following the introduction of food aid and Green Revolution technologies.

\section{GRAPH 1}

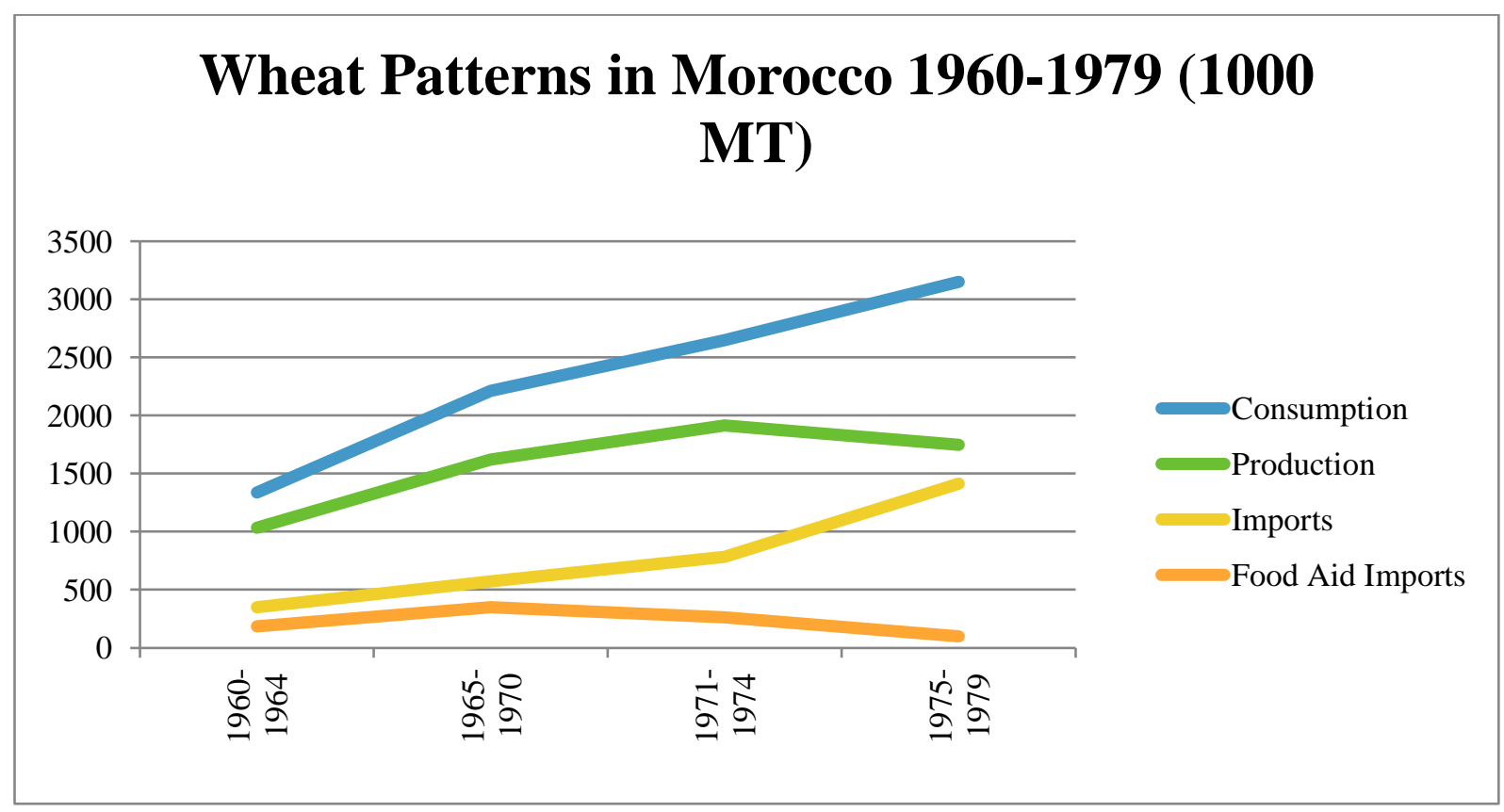

(Hodges 1983, 111 \& 140) (Index Mundi 1c n.d.)

Overall, consumption grew divorced from domestic production and was sustained through imports. And, by the end of the 1970s, wheat consumption had more than doubled. The accelerated growth in consumption surpassed domestic output and caused wheat imports to rise 22 percent annually (Hodges 1983, 138).

Today, Moroccan wheat consumption is four times the global average (Arrisueño, Ahmed, Hamrick, and Nahapetyan 2016), which is a development that began post- 
independence. Between 1960 and 1979, per capita wheat consumption grew about 65 percent from 103kg/year per capita to $170 \mathrm{~kg} /$ year per capita (Hodges 1983, 111); and as of 2015 , per capita wheat consumption had swelled 150 percent to $258 \mathrm{~kg} / \mathrm{year}$ from the year 1960 (Hodges 1983, 111 and Arrisueño, Ahmed, Hamrick, and Nahapetyan 2016)1. Notably, nearly two-thirds of Moroccan wheat consumption is soft wheat (Fardaoussi and Hanson 2016).

The period from 1960 to 1979 is notable because it comprises when food aid and Green Revolution technology transfers penetrated Morocco and when the government engaged in its cheap wheat policy. The span from 1980 to present is a period of liberalization. Government policies shifted focus and investment into export-oriented agriculture. Under these policies, the dichotomous nature of farming in Morocco, which was a factor of inequality linked to land availability and access to irrigation, capital, and technology, was further engendered. The production of vegetables and citrus increasingly left the country as exports and a struggling economy failed to provide meaningful wages to Moroccans, making khobz a cheap substitute for foodstuffs that became increasingly expensive.

To satisfy demand, Morocco evolved from a net exporter of wheat to a net importer. Swearingen (1987), moreover, concludes that during this time, "Morocco...steadily lost the ability to feed itself" (184). As such, Morocco's attempt to achieve food self-sufficiency languished. Given the challenges of land segmentation and limited access to irrigation as demand for soft wheat increased, the government lacked the ability to reverse its dependency on wheat imports. As a result, the domestic sector

1 Calculation Formula for Hodges findings (graphed above):

((Consumption) $\mathrm{x}$ 1000)/Average Population=annual per capita consumption $(\mathrm{kg})$ 
failed — and continues to fail— to provide enough soft wheat to satisfy the ever-increasing demands.

Failure to sufficiently expand domestic production of wheat has forced the government to satisfy demand for low price khobz through heavy imports and subsidies. Political stability is highly sensitive to food availability and food prices, which was demonstrated in the 1980 bread riots and also in the more recent protests of 2007 ( $\mathrm{Al}$ Jazeera 2007). Accordingly, imports of soft wheat continue to rise. Graph 2 highlights Morocco's continued reliance on wheat imports to satisfy demand.

GRAPH 2

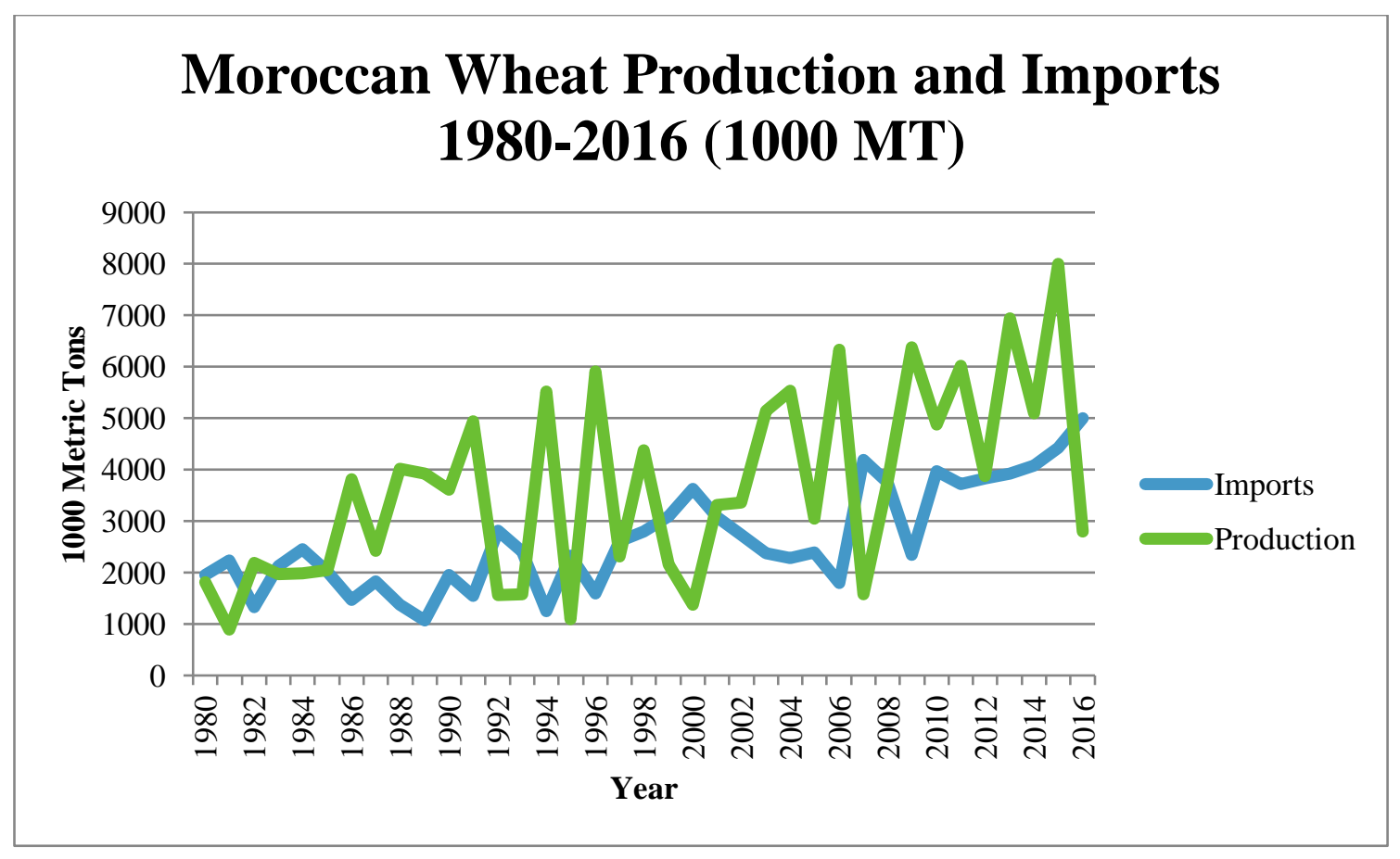

(Index Mundi 1c and 1d)

Even as the trend in wheat production is rising, it remains highly volatile. Imports show an upward trend as well, particularly in years when domestic yields slumped. Moreover, 
Arrisueño, Ahmed, Hamrick, and Nahapetyan (2016) point out that in 2015, one-third of all consumed wheat was imported despite grain farming occupying 70 percent of agricultural land and 47 percent of planted grain being soft wheat (Fardaoussi and Hanson 2016). Morocco's reliance on imports is a result of a flailing domestic sector coupled with unprecedented demand. The domestic sector struggles because soft wheat farming, while extensive, predominates on sub-optimal land lacking irrigation and mechanization. Thus, in the face of rising demand, which occurred as unmitigated amounts of soft wheat entered the markets, imports increased to match demand.

In sum, rising khobz consumption was factor of the Green Revolution and food aid perpetuated by the United States alongside domestic policy subsidizing and encouraging its consumption. Increased demand encouraged small farmers to maintain soft wheat production and imports to increase. Morocco's wheat dilemma, however, is not solely about production, consumption, and import patterns. The trends outlined above have far-reaching outcomes, extending to grain diversity, economic performance, food security, and rural development.

\section{A. Grain diversity}

From an ecological standpoint, Moroccan wheat policies have encouraged the homogenization of grain production. As previously noted, grain farming occupies 70 percent of all agricultural area and soft wheat is 47 percent of this total. Further, of the 11.5 million tons of grain harvested in 2015 , over 5.5 million were soft wheat. In other words, 47 percent of all harvested grain was soft wheat, while durum wheat accounted for only 18 percent, and barley 35 percent (Fardaoussi and Hanson 2016). 
The predominance of soft wheat was not, however, always the norm. In fact, in the early 1960's and prior, most wheat produced was durum wheat, which is most often used in couscous. The shift in the type of wheat being produced is notable because it demonstrates the shift occurring in Moroccan diet practices as both the nutrient composition and use of these wheats are very different. And, at the time, barley cultivation occupied more land than wheat. Yet, post 1960's, in the wake of changing wheat patterns and policies, wheat consumption grew 12 percent annually, while barley and corn consumption fell two percent per year (Hodges 1983, 115). As demand fell, so did production. Graph 3 illustrates the shift in planted area of both wheat and barley from 1960 to 2016 . Wheat is not aggregated by soft or durum because data on that component is not readily available over the given time period, but it can be inferred given the data presented above.

GRAPH 3

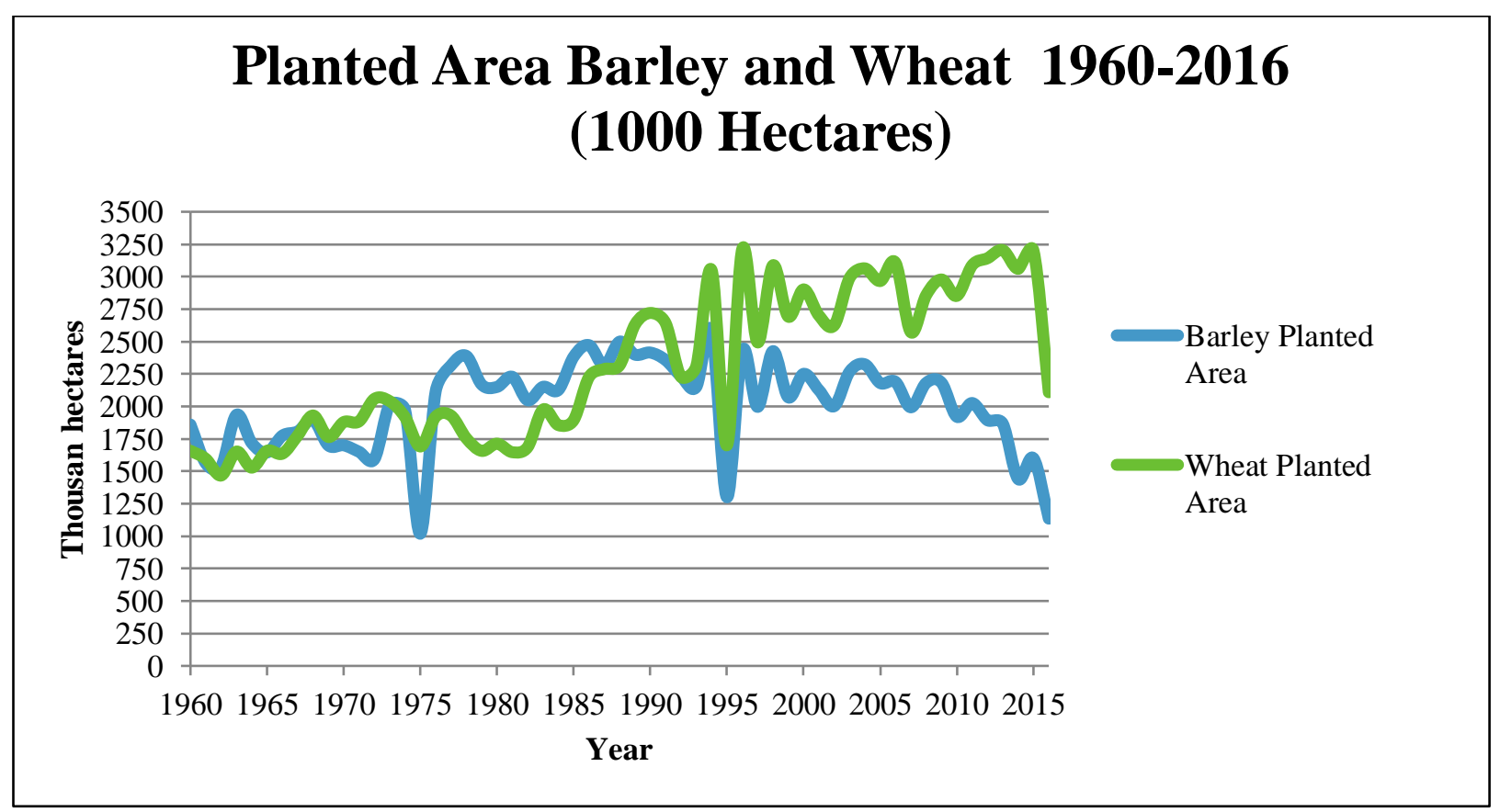

(Index Mundi 1a and 1b) 
The increase in wheat acreage likely resulted in the decrease in barley acreage. Knowing that grain production was and remains concentrated among small rural farmers (Swearingen 1987, 145 and Diao, Doukkali, and Yu 2008), a decrease in barley and durum production alongside a simultaneous increase in soft wheat output, leads us to infer that small farmers switched seeds to produce soft wheat, which enjoyed the benefits of HYV seeds and was in high demand as a low-cost ingredient in khobz. We can conclude that soft wheat production catalyzed the homogenization of grain production persisting in present time. Still, in the face of grain homogenization and increases in soft wheat production, domestic production failed to meet demand, and therefore, imports and price subsidies were employed to mitigate availability and high costs to consumers. Together, these strain Morocco's economic performance.

\section{B. Economic Performance}

In the face of chronic shortages between demand and domestic production of soft wheat and a struggling economy post-independence, the Moroccan government embraced imports and price subsidies to relieve high consumer costs. The trend of rising imports and price subsidies become critical when considered alongside Morocco's flailing economy. Morocco's GDP per capita remains low at 8200 USD, and its capacity to remedy stagnant growth is hampered by low revenues and high government spending (CIA n.d.). Soft wheat, on account of trade costs and price subsidies, contributes to high government spending. 
High import costs erode the balance of trade in Morocco. Morocco's trade deficit was 17.1 billion dollars in 2014; it peaked in 2008 and again in 2012, when it surpassed 18 billion dollars (OEC n.d.). Notably, 2008 and 2012 both followed years of unusually high wheat prices internationally (World Bank n.d.), which is significant for Morocco because wheat imports amount to 1.42 billion dollars and are 3.2 percent of Morocco's total imports. Wheat is the fifth largest import behind refined petroleum, crude petroleum, petroleum gas, and cars (OEC n.d.). The predominance of wheat among imports is especially considerable given that wheat production occupies so much of Moroccan agrarian land.

Morocco also employs price subsidies for both imported and domestically produced wheat in order to depress the price for consumers. As of 2014, 20 percent of Morocco's annual budget went towards subsidizing essentials-khobz, electricity, and fuel. Though I was unable to find data specifically on the cost of subsidizing soft wheat and khobz in the market, Fardaoussi and Hanson (2016) finds that Morocco subsidizes the price of more than one million MT of soft wheat.

In 2014, Morocco signed a loan with the IMF. As a condition for the loan, Morocco had to reduce deficit spending, including cuts to subsidies. Facing resistance by the population, Morocco's finance minister subsequently announced that, "The government is doing their best to make sure the price of bread won't change, because bread is related to our culture...It's a very special product" (Thakore 2014). As of 2016, wheat-khobz-subsidies remain an integral part of Morocco's domestic spending (Fardaoussi and Hanson 2016). Moreover, even as the government works to abate deficit spending, subsidies for soft wheat and khobz remain a priority. 
Soft wheat imports and subsidies stymie Morocco's economic performance by increasing government spending. While Morocco's domestic production is hefty, it is also insufficient in satisfying demand. The lack of food self-sufficiency, particularly in the face of large domestic production, thus erodes economic performance. Yet, the application of price subsidies in Morocco help insure food security. Therefore, cutting price subsidies presents a problem for food security, which will be analyzed in the following section.

\section{Food Security}

Food security rests in the government's ability to provide wheat at a low price to consumers. To achieve this, Moroccan agriculture could be used as a vehicle for food security. Relying on domestic food production reduces external spending and stimulates the local economy. However, Morocco's wheat policies have worked against this goal. While national demand for fruits and vegetables is fully met by local production, only 55 percent of the demand for grain is supplied locally despite 70 percent of agricultural land being allotted to grain cultivation (World Bank 2013, 70). Thus, demand for soft wheat coupled with high imports - vulnerable to external price shocks — and subsidy schemes threaten food security. Huppé, Shaw, Dion, and Voora (2013) explain that, "food price is one of the most significant [variables] in determining the state of food security in the world." They add that Morocco's dependence on food imports and its weak economic performance make it the most susceptible country in the MENA to external shocks. Dependence on imported soft wheat to satisfy demand and the use of subsidies to fix the 
price of wheat creates a great fiscal strain on the government, which struggles to supply goods during high-price periods.

For example, Morocco experienced a catastrophic drought in 2016 during which precipitation fell 77 percent below normal. Grain output was particularly affected, with total harvest slumping to 54 percent of the previous year's, forcing Morocco to double its imports to satisfy demand (Ruitenberg 2016). Such an increase is particularly damaging because soft wheat prices show an upward trend internationally (World Bank n.d.). Graph 4 illustrates the rise and fluctuation in soft wheat prices globally compared to average food prices.

GRAPH 4

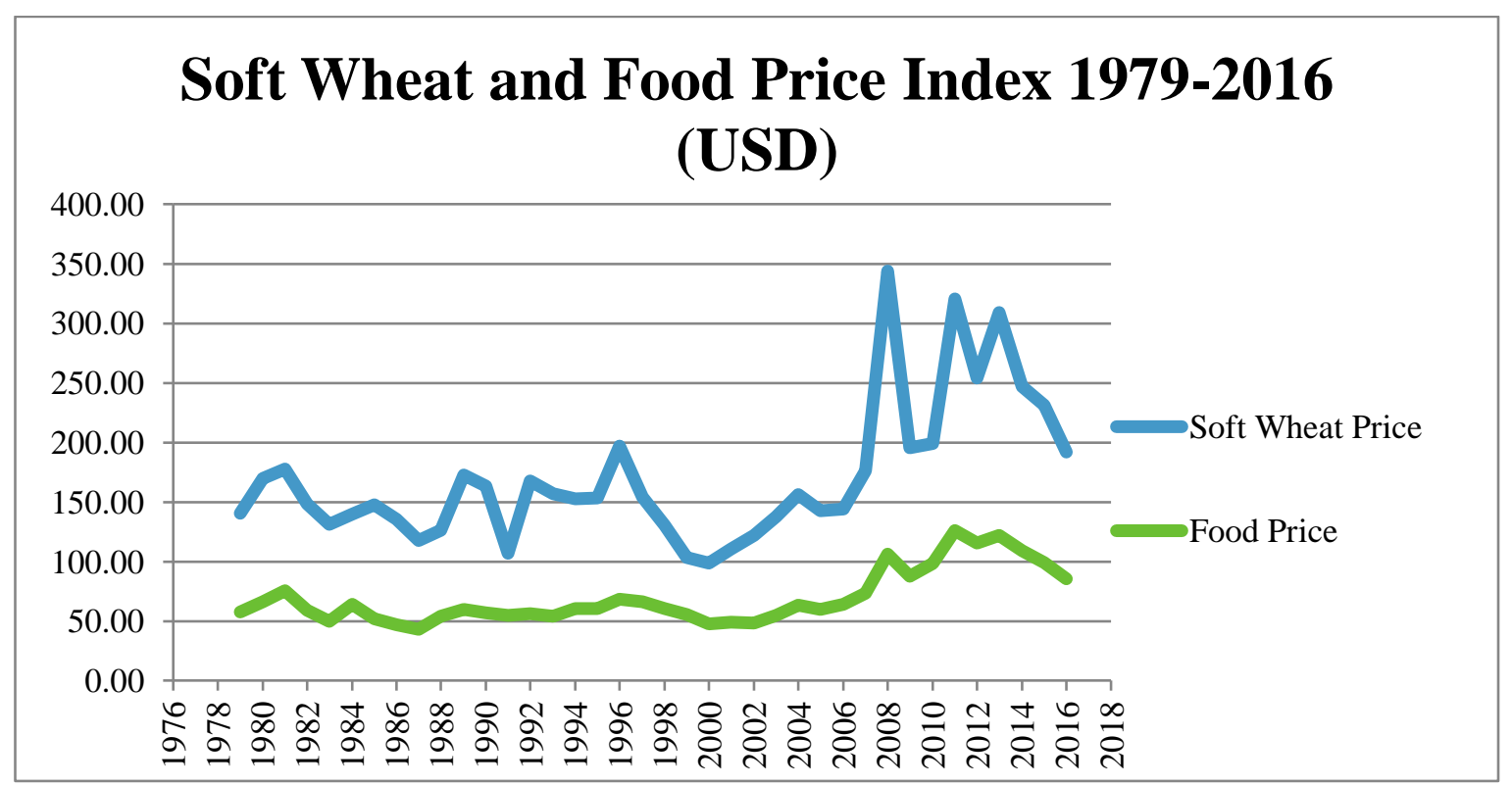

(Gapminder)

Soft wheat and food prices have exhibited volatile fluctuations, but the overall trend has been on the rise, particularly since 2007. Price volatility yields further strains on 
government financial resources because Morocco's demand for wheat imports is inelastic, which means price does not impact demand (Arrisueño, Ahmed, Hamrick, and Nahapetyan 2016). Not only must the government import wheat at inflated prices, but it also subsidizes the price for domestic consumption. As a result, Morocco faces steep fiscal risks in the face of food price volatility, representing a threat to food security.

Food security is impeded by inadequate economic performance because the government risks steep price hikes for consumers if it is unable to cover price subsidies. 58 percent of Moroccan calorie intake is derived from cereal grains, and wheat is 71 percent of the total cereal intake (Santos and Ceccacci 2015). Thus, if the government became financially unable to cover the import and subsidy costs, external price shocks would impact all consumers, especially the poor. On average, Moroccans spend 40 percent of their income on food, yet this increases to 75 percent among poor households (Ghanem 2015). Therefore, in the face of price shocks, the poor would be disproportionately affected. Untenable wheat policies endanger food security nationally, and given that Morocco's poor are primarily concentrated in agriculturally dependent areas, the greatest threat is to the rural poor. The poverty wrought in rural, agriculturally dependent areas impacts rural development as well.

\section{Rural Development}

Given the predominance of small farms, rural development in Morocco is intrinsically linked to the outcomes of small farmers, who currently face several barriers. The World Bank (2013) cites lack of irrigation and mechanization as two of the biggest challenges to small farmers (70-71), and argues that the agrifood sector's growth 
potential is constrained by the dualistic nature of farming in Morocco (5). Wheat production is concentrated among small farmers occupying non-irrigated and nonmechanized, highly segmented land, which has received little investment because agricultural development initiatives were directed to the non-wheat, agrarian export sectors. This is largely because these investments occurred alongside the influx of food aid, Green Revolution technology transfers, and market de-regulation through neoliberalism. Moreover, given that wheat flowed into the country in large, cheap supplies while investment into the domestic wheat producing sector remained low, and that wheat yields less profits for Moroccan producers and wheat is farmed on less favorable, rain-fed, and fragmented land, the sector languished.

The wheat production sector struggles from a myriad of problems, chief among these are occupation of non-fertile land, lack of mechanization, and reliance on rain fed irrigation, which are the norm among small farmers. The inefficiency that stems from these is partially actualized in the wheat sectors inability to offered sustained employment. As such, grain production-mostly soft wheat—currently occupies 70 percent of the utilized agricultural area, but only accounts for 10 percent of employment in agriculture (World Bank 2013, 70). This raises another problem with Moroccan soft wheat patterns: its production, which monopolizes agricultural land, does not provide many employment opportunities.

As such, reform solely of the soft wheat sector is not a catalyst for rural development because its reach, as far as employment, is so minimal. Still, it is important to understand why the outcomes for soft wheat farmers are so dismal. Soft wheat farming is indicative of the larger power structures at play in the Moroccan rural landscape- the 
dominance of large farmers and the wealth extracted by them through exporting crops, as well as the problems facing small farmers through their reliance on rain fed irrigation, occupation of non-fertile land, and lack of mechanization. All these factors contribute to a lack of rural development. This lack of rural development is catastrophic for Morocco because it has a large agrarian population and the national economy is dependent on agriculture for both GDP and employment. As a result, stalled development in rural areas correlates to floundering development initiatives nationally. 


\section{Conclusion}

Wheat policies enacted by the Moroccan government were necessarily influenced by food aid and the Green Revolution, both of which precipitated an influx of soft wheat into Morocco. The policies crafted by the Moroccan government subsidized soft wheat consumption and ushered in a period of unprecedented growth in demand for khobz, reshaping domestic agricultural production and encouraging a spike in imports of soft wheat. Overtime, khobz consumption patterns homogenized grain production, eroded economic performance, impaired food security, and hampered rural development.

The aforementioned outcomes are neither isolated nor independent experiences. Increased consumption fueled the rise in domestic production and the homogenization of grain farming to match rising demand. Despite the uptick in wheat produced domestically, the inefficiency of the sector hampered production in its ability to satisfy demand. Therefore, imports were employed and price subsidies, subsequently, to maintain low consumer prices. Together, high imports and price subsidies impact Morocco's economic performance. And, struggling economic performance strains food security by limiting Morocco's ability to maintain price subsidies in the face of rising costs. The tenuous food security is most dangerous for poor, rural consumers who suffer from a lack of rural development. And, this lack of rural development further contributes to the tenuous food security that then impacts economic performance. Moreover, the effects and outcomes of Moroccan soft wheat patterns of production, consumption, and import are inherently related.

Under Maroc Vert, Morocco is currently in the midst of a major overhaul of its agricultural sector. In a letter to the World Bank, Morocco's Minister of Agriculture and 
Maritime Fisheries writes, "Agriculture is an important pillar for Morocco's development. Its economic and social weight, the key linkage it provides to the rural areas, and its myriad functions in the food, economic, social, and environmental areas, in particular, make it a powerful engine of our country's development” (World Bank 2013, 70). Indeed, as a cornerstone of the Moroccan economy and stimulus for rural development, agriculture in Morocco contributes to nearly fourteen percent of GDP, twenty-three percent of exports, and forty percent of employment opportunities nationally as well as eighty percent in rural areas (Berkat and Tazi 2006).

In seeking to remedy rural and national development challenges through improvements to the agricultural sector, Maroc Vert adopts a five-pillar focus in attempting to embrace a holistic approach to agricultural improvement. However, doubt (Hicks 2015) exists as to whether Maroc Vert is capable of extending its effects to small farmers, or whether it will replicate past development initiatives that caused results to skirt this sector. For example, irrigation investments are directed towards large, exportoriented farms. Instead, for small farmers to gain access to irrigation, mechanization, and crop diversity, Maroc Vert encourages contract farming. Contract farming is an imperfect solution to a very complicated and nuanced problem to which soft wheat is one aspect. As was discussed, wheat farming represents only a small segment of total agricultural employment, so solely focusing on this segment is not feasible. Introducing contract farming, can begin to touch on some of the issues wrought in soft wheat farming, which are also a part of the larger narratives of small farmers in Morocco.

Yet, before beginning to evaluate whether contract farming or any suggested solution has the potential to allay issues associated with patterns of wheat production, 
consumption and import, comprehending the root causes of such issues is needed. Without this context and a deep understanding of the nuance behind the current experienced outcomes, solutions are likely to flounder. Moroccan wheat demand is high because international and national policies subsidized its consumption. Moroccan farmers are unable to meet high domestic demand because of the unfavorable land and farming conditions under which wheat is produced domestically. These unfavorable conditions were institutionalized through policies under the French Protectorate, post-independence by the government, and also international actors. The prevailing wheat patterns are a factor of a myriad of policies ultimately tied to Moroccan's demand for khobz. Moreover, without at least acknowledging this situation that has very real and unsustainable outcomes, solutions will be unable to remedy these outcomes, and rural underdevelopment will persist.

Ultimately, for agricultural development to occur, wheat patterns and polices will need to be rectified. Yet, this "rectification" is complicated. Given Moroccan's caloric dependence and cultural affection for khobz, any policy that limits its availability or increases its price is likely to be met with steep backlash. Yet, the prevailing framework is also unsustainable and will likely result in eventual price hikes when the government can no longer manage import and price subsidy costs. This thesis explored in detail the nuance of the prevailing situation through analyzing both its roots and ramifications. Areas for further study include the ways in which soft wheat consumption has impacted health in Morocco and the implementation of contract farming in Morocco among wheat farmers. 
Morocco's economic, political, and cultural histories are inextricably intertwined with agriculture, and sown within this is soft wheat farming. The French Protectorate sought to capitalize on this millennia long practice, but ultimately eroded the sector. The erosion continued into independence and was further spurred by international intervention and mismanaged policies. Presently, Morocco is seeking to remedy these results, but is restricted by wheat patterns of production, consumption, and import. The necessity of political stability and economic longevity mandates the reparation of these patterns and an improvement of the policies informing them. Wheat patterns are a mainstay of Morocco's agricultural narrative that embody the present problems facing Moroccan agriculture and especially small farmers; and, the implication of these unchecked patterns extend to issues of grain diversity, economic performance, food security, and rural development.

Soft wheat blends with salt, sugar, yeast, and water and forms into a firm dough that is then kneaded, rested, and rounded and eventually placed into the cave of fiery ovens. Baked to the perfect balance of crisp crust and soft, fluffy crumb, khobz is the result of this millennia long tradition. While the composition of khobz has changed, its value to Moroccan society remains a stalwart of the culture. To be in Morocco is to eat $k h o b z$. And, to eat $k h o b z$ is to slowly but concretely understand Morocco. "Manage with bread and butter until god sends honey." This is to say that throughout Morocco's rich history and oral tradition, khobz remains a pillar of the culture. Its historical importance is not lost on the people living there today. While patterns tied to khobz consumption are meddled with challenges to overcome, Morocco teaches us that no matter the 
circumstance, khobz has and will remain a vehicle for subsistence and survival and life and celebration. 


\section{Works Cited}

Al Jazeera. 2007. "Morocco Rolls Back Bread Price Hike." Al Jazeera English. September 25. Accessed January 4, 2017.

Arrisueño, Gabriel, Ghada Ahmed, Danny Hamrick, and Sona Nahapetyan. 2016. "Moroccan Food Security and the Wheat Value Chain." Duke MINERVA. Accessed October 5, 2016.

http://www.cggc.duke.edu/pdfs/2016.03.08_FINAL_CGGC_Moroccan\%20Food\%20Sec urity\%20and\%20the\%20Wheat\%20Value\%20Chain.pdf

Barrett, Christopher B. 1998. "Food Aid: Is It Development Assistance, Trade Promotion, Both, or Neither?" American Journal of Agricultural Economics 80(3): 566-71. http://www.jstor.org/stable/1244559

Barrett, Christopher B. 2006. "Food Aid's Intended and Unintended Consequences." The Food and Agricultural Organization of the United Nations. Accessed November 12, 2016.

http://www.fao.org/3/a-ag301t.pdf

Berkat, O., and M. Tazi. 2006. "Country Pasture/Forage Resource Profiles Morocco." The Food and Agricultural Organization of the United Nations. Accessed December 5, 2016.

http://www.fao.org/ag/Agp/agpc/doc/counprof/PDF\%20files/Morocco-English.pdf

Bijman, Jos. 2008. "Contract Farming in Developing Countries: An Overview." Development Cooperation Ministry of Foreign Affairs. Accessed December 1, 2016. https://www.wur.nl/upload_mm/5/c/b/79333121-6f4b-4f86-9e8e0a1782e784d6_ReviewContractFarming.pdf

Cleaver, Harry M. Jr. 1972. "The Contradictions of the Green Revolution." American Economic Association 62(1 \& 2): 177-186. http://www.jstor.org/stable/1821541

CIA. n.d. "Morocco." Central Intelligence Agency World Factbook. Accessed October 10, 2016. https://www.cia.gov/library/publications/the-world-factbook/geos/mo.html

Davis, Diana K. 2006. "Neoliberalism, Environmentalism, and Agricultural Restructuring in Morocco." The Geographical Journal Geographical Journal 172(2): 88-105. doi: 10.1111/j.1475-4959.2006.00204.x

Diao, Xinshen, Rachid Doukkali, and Bingxin Yu. 2008. "Policy Options and Their Potential Effects on Moroccan Small Farmers and the Poor Facing Increased World Food Prices: A General Equilibrium Model Analysis." International Food Policy Research Institute. Accessed December 5, 2016. http://ebrary.ifpri.org/utils/getfile/collection/p15738coll2/id/27038/filename/27039.pdf 
Fardaoussi, Mohammed and Sarah Hanson. 2016. "Morocco Grain and Feed Annual." USDA: Global Agriculture Information Network. Accessed September 16, 2016. http://gain.fas.usda.gov/Recent\%20GAIN\%20Publications/Grain\%20and\%20Feed\%20A nnual_Rabat_Morocco_3-30-2016.pdf

Hermann, Roland, Carlo Prinz, and Patricia Schenck. 1992. "The Relationship between Food Aid and Food Trade: Theoretical Analysis and Quantitative Results." International Association of Agricultural Economists. Accessed August 10, 2016. http://ageconsearch.umn.edu/bitstream/197872/2/agecon-occpapers-1992023\%5B1\%5D.pdf

Hodges, Christopher Brown. 1983. "Low Income Countries and the World Wheat Trade." PhD diss., University of Minnesota.

Hicks, Celeste. 2015. "Morocco's Progress on Food Security Acknowledged by UN but Work Remains." The Guardian. October 31. Accessed February 1, 2017. https://www.theguardian.com/global-development/2015/oct/27/morocco-food-securityun-special-rapporteur-hilal-elver-plan-maroc-vert

Huppé, Gabriel A., Sabrina Shaw, Jason Dion, and Vivek Voora. 2013. "Food Price Inflation and Food Security: A Morocco Case Study." International Institute for Sustainable Development. Accessed November 10, 2016. http://www.iisd.org/pdf/2013/food_price_inflation_morocco.pdf

Index Mundi 1a. n.d. "Morocco Barley Area Harvested by Year." Accessed November 6. http://www.indexmundi.com/agriculture/?country=ma\&commodity=barley\&graph=areaharvested

Index Mundi 1b. n.d. "Morocco Wheat Area Harvested by Year." Accessed November 6. http://www.indexmundi.com/agriculture/?country=ma\&commodity=wheat\&graph=areaharvested

Index Mundi 1c. n.d. "Morocco Wheat Imports by Year." Accessed November 6. http://www.indexmundi.com/agriculture/?country=ma\&commodity=wheat\&graph=impo $\underline{\text { rts }}$

Index Mundi 1d. n.d. "Morocco Wheat Production by Year." Ac Accessed November 6. http://www.indexmundi.com/agriculture/?country=ma\&commodity=wheat\&graph=produ ction

Ghanem, Hafez. 2015. "Agriculture and Rural Development for Inclusive Growth and Food Security in Morocco." Brookings Institution. Accessed December 5, 2016. https://www.brookings.edu/wp-content/uploads/2016/07/Agriculture_WEB_Revised.pdf

Global Yield Gap Atlas. n.d. "Morocco." Accessed December 4. http://www.yieldgap.org/morocco 
Moroccan Government. n.d. "Agriculture." Embassy of the Kingdom of Morocco in the USA. Accessed October 11, 2016. http://www.embassyofmorocco.us/agriculture.htm

OEC. n.d. "Morocco." The Observatory of Economic Complexity. Accessed October 31, 2016. http://atlas.media.mit.edu/en/profile/country/mar/

Pingali, Prabhu. 2012. "Green Revolution: Impacts, Limits, and the Path Ahead." Proceedings of the National Academy of Sciences 109(31): 12302-2308. http://www.pnas.org/content/109/31/12302.full

Ruitenberg, Rudy. 2016. "Morocco Prays to Save Wheat Fields After Catastrophic Drought." Bloomberg. Accessed November 3, 2016.

https://www.bloomberg.com/news/articles/2016-03-03/morocco-prays-to-save-wheatfields-after-catastrophic-drought

Santos, Nuno, and Iride Ceccacci. 2015. "Egypt, Jordan, Morocco and Tunisia Key Trends in the Agrifood Sector." Food and Agricultural Organization of the United Nations. Accessed December 5, 2016. http://www.fao.org/3/a-i4897e.pdf

Stavrianos, Leften Stavros. 1981. Global Rift: The Third World Comes of Age. New York: Morrow.

Swearingen, Will D. 1987. Moroccan Mirages: Agrarian Dreams and Deceptions, $1912-$ 1986. Princeton: Princeton UP.

Thakore, Ishan. 2014. "Deficit Pushes Morocco to Cut Subsidies." Al Jazeera English. Accessed October 31, 2016.

http://www.aljazeera.com/news/middleeast/2014/03/deficit-pushes-morocco-cutsubsidies-2014327823976605.html

UNDP. 2013. "Income Gini coefficient." Human Development Report. United Nations Development Programme. Accessed January 5, 2017. http://hdr.undp.org/en/content/income-gini-coefficient

UNDP. 2015. "Morocco." Human Development Report. United Nations Development Programme. Accessed January 5, 2017. http://hdr.undp.org/en/countries/profiles/MAR

United States. Cong. House. Sub Committee on National Security Policy and Scientific Developments. 1969. Symposium on Science and Foreign Policy: The Green Revolution. Dec 5. 91 st Cong.

Wacziarg, Romain, and Karen Horn Welch. 2008. "Trade Liberalization and Growth: New Evidence." The World Bank Economic Review 22(2): 187-231. doi: $10.3386 / w 10152$ 
Wolf, Edward C. 1986. "Beyond the Green Revolution: New Approaches for Third World Agriculture.” World Watch Paper \#73. Accessed July 8, 2016.

http://eric.ed.gov/?id=ED275504

World Bank. 1978. "Toward Greater Food Security in Morocco: An Overview of Issues and Prospects." AGREP. Accessed November 12, 2016.

http://documents.worldbank.org/curated/en/659211468276890295/pdf/AGP12000Towar d00Box371941B00Public0.pdf

World Bank. 2013 "Second Policy Loan in Support of the Plan Maroc Vert." World Bank. Accessed December 5, 2016.

http://documents.worldbank.org/curated/en/179751468279281674/pdf/734100PGD0P127 0Official0Use0Only090.pdf

World Bank. 2015. "Contracting Agricultural Production." Accessed February 1, 2017. http://eba.worldbank.org/reports/ /media/WBG/AgriBusiness/Documents/Reports/2015/ EBA2015-Contracting-agriculture-production.pdf

World Bank. n.d. "Agriculture \& Rural Development." World Bank Data. Accessed December 5, 2016. http://data.worldbank.org/topic/agriculture-and-rural-development 